Bond University

Research Repository

\title{
Institutions and gender empowerment in greece
}

\author{
Dellios, Rosita
}

Published in:

Institutions and gender empowerment in the global economy

\section{Licence:}

Unspecified

Link to output in Bond University research repository.

Recommended citation(APA):

Dellios, R. (2008). Institutions and gender empowerment in greece. In Institutions and gender empowerment in the global economy (pp. 277-292). World Scientific Publishing.

\footnotetext{
General rights

Copyright and moral rights for the publications made accessible in the public portal are retained by the authors and/or other copyright owners and it is a condition of accessing publications that users recognise and abide by the legal requirements associated with these rights.
}

For more information, or if you believe that this document breaches copyright, please contact the Bond University research repository coordinator. 


\section{Bond University}

\section{ePublications@bond}

Humanities \& Social Sciences papers

Faculty of Humanities and Social Sciences

6-1-2008

\section{Institutions and gender empowerment in Greece}

Rosita Dellios

Bond University, rosita_dellios@bond.edu.au

Follow this and additional works at: http://epublications.bond.edu.au/hss_pubs

Part of the Women's Studies Commons

\section{Recommended Citation}

Dellios, Rosita, "Institutions and gender empowerment in Greece" (2008). Humanities \& Social Sciences papers. Paper 279.

http://epublications.bond.edu.au/hss_pubs/279

This Book Chapter is brought to you by the Faculty of Humanities and Social Sciences at ePublications@bond. It has been accepted for inclusion in Humanities \& Social Sciences papers by an authorized administrator of ePublications@bond. For more information, please contact Bond University's

Repository Coordinator. 
'Institutions and Gender Empowerment in Greece', in Kartik C. Roy, Hans C. Blomqvist, and Cal Clark, (eds), Institutions and Gender Empowerment in the Global Community, Singapore/London: World Scientific Publishing Co (WSP)/ Imperial College Press. Ch. 12, pp. 275-290 (forthcoming, 2008).

\title{
Institutions and Gender Empowerment in Greece
}

\author{
Rosita Dellios
}

\section{Introduction}

The Hellenic Republic (Greece) is a multiparty parliamentary democracy and a member of the European Union which has influenced standards for women's rights. Greece's 1975 Constitution reflects the principles on equality found in the UN International Convention on eliminating discrimination against women (Act1342/83) and in the European Social Charter (Act1426/84). ${ }^{1}$ Indeed, international regimes are a notable force in favour of Greek women's empowerment. Gaining the right to vote in 1952 - after three decades of struggle by women's emancipation groups within Greece - is a case in point. Having become a signatory to the United Nations Convention on Women's Political Rights of 1951, the Greek government introduced a Bill to parliament the following year giving full political rights to women. The Bill was passed and women first voted in the national election of 1956. Since then, Greece has ratified the Convention on the Elimination of all forms of Discrimination Against Women as well as other relevant treaties.

\section{Importance of women in economic and social development in Greece}

Greek women have contributed to nation-building efforts in economic and socio-political forms. As early as 1887 through Kallirhoe Parrin's publication of The Ladies' Journal, Greek feminists were vocal in the shaping of Greek society. By the 1920s, the National Council of Greek Women, which represented a number of women's groups, published its views through the Greek Woman, a monthly that was joined by Women's Struggle - the bulletin of the Greek League of Women's Rights founded by Avra Theodoropoulou and Maria Negraponti. Its cover page in the inaugural issue in 1923 demanded "the same political, civil and economic rights for men and women".2 Both the League and the magazine continued into the $21^{\text {st }}$ century, with Xanthi Petrinioti as editor and president since 2003, though disruptions occurred during the 1930s under the Metaxa dictatorship when civil liberties were suspended and later in 1967-1974 during the press censorship imposed by the military junta.

Bold words were matched by heroic deeds during World War II when Greek women fought in the resistance alongside men. After the war, women became wage earners in a new industrializing society with its emerging middle class. Greece's involvement in international governmental organizations, the women's movement, and the demands of industry, resulted in a number of fundamental advances for women. By the 1950s women gained voting rights, in the 1960s and 1970s more and more women joined the paid workforce, and by the 1980s key social legislation in favour of women was passed. In the decade 1977-1887 alone, women's participation rate in the workforce increased from 32 per cent to 43 per cent. ${ }^{3}$ By 2004, the participation rate climbed to 54.1 per cent, but this was comparatively low in EU terms with most EU countries scoring above 60 per cent. ${ }^{4}$ Also, women were now working primarily in the services sector rather than agriculture, a reflection of the Greek economy's changing structure (services constitute almost three-quarters of GDP) and the opportunities available for employment. 


\section{Socio-economic status vis-à-vis men}

According to research conducted by the Greek National Centre for Social Research (EKKE) in 2002, the socio-economic status of women in relation to men remains traditional: the breadwinners are predominantly men, and the homemakers women. Specifically, about twice as many men (88 per cent) were employed when surveyed compared to women (45 per cent), while women spent on average almost four times as many hours on housework per week (34 hours) compared to men (nine hours), and almost twice as much time on childcare per week (15 hours

compared to eight). ${ }^{5}$ The unemployment rate among women (12.9 per cent) was three times that of men ( 4.7 per cent). ${ }^{6}$

Women who did find work in paid employment encountered difficulties in integrating because of inflexible work hours, lack of affordable childcare facilities, and a paucity of professional development and vocational programs. The patriarchal family structure prevails to the point that the dowry system is still practised (even though legally abolished), and violence against women remains high for cultural reasons: "To the Greek mentality, a slap in the face is a form of emotional communication for both sexes; and the Mediterranean temperament excuses such gestures as an indication of passion ... The relationships amongst the two sexes are relationships of power and subordination, not of companionship and respect."7 Moreover, domestic violence is still widely viewed as a private affair, not to be reported or condemned by external parties. Yet it is singled out as a human rights violation in the US Department of State's 2005 country reports on human rights practices. ${ }^{8}$

\section{Indicators $^{9}$}

Greece’s GDP per capita is $\$ 23,518$. Its total population is 10.6 million, of whom 5.2 million are male and 5.4 million are female. Urban dwellers constitute two-thirds of the population. Greece's high standard of living is reflected in its Human Development Index ranking of 24th in 2006. The exception is Greece's Roma population (estimated 100,000 to 350,000), whose living conditions were found in 2005 to be "substandard" and whose children had "inedequate access to schools". ${ }^{10}$ Income distribution by household income or consumption is 3 per cent for the lowest 10 per cent and 28.3 per cent for the highest 10 per cent. Distribution of family income - Gini index is 35.1 (2003). There is free education at all levels, with nine years compulsory. The adult literacy rate is high at 97.5 per cent, as is life expectancy at birth - 79.2 years for the total population (76.7 for males and 81.9 for females). The infant mortality rate is 5.4 deaths for every 1,000 live births (5.9 male and 4.8 female). As with many developed countries, the total fertility rate is low, but Greece's is among the world's lowest -1.3 children. Abortion and contraception have been legal since the 1980s. Abortion is prevalent, while use of oral contraception is reportedly low: 5 per cent compared to 35 per cent in other countries in Europe in the 1990s. ${ }^{11}$ Condom use tends to be promoted for prevention of the spread of HIV/AIDS (which has a prevalence in Greece of 0.2 per cent), rather than for birth control. The high incidence of abortion - thought to be two or three times the live birthrate but this cannot be verified because few abortions are registered - is attributed to economic considerations (the chief cause identified by women themselves), poor childcare infrastructure for working mothers, and inadequate information on preventative contraceptives. ${ }^{12}$

\section{Decomposition of Exchange Entitlement Theory}

The informal institutions, and to some extend formal ones also, may be regarded as hindrances preventing Greek women from attaining the same level of empowerment as men. Even with 
physical labour as her only endowment, the continued prevalence of "classic patriarchy” means that a woman from an agricultural or fishing community is still expected to fulfil her traditional domestic role and to uphold the honour of the family. Her ambitions are channeled into the domestic sphere and family networks. There has, however, been a greater emphasis in the villages on the education of daughters. This has meant an overcoming of the "ideology of seclusion" so that daughters are allowed to live away from home for tertiary education. Success in higher education and the hoped-for acquisition of professional employment is seen to bring honour to the family and to improve a daughter's marriage prospects. So while a women attains the higher stages of Sen's exchange entitlement theory, it is not without social encumbrances. Educated or not, a women is expected to conform to community standards of ideal Greek womanhood. The primary component of this is motherhood. Mothers are highly esteemed in Greek society and grandmothers act as matriarchs within the family, while fathers and grandfathers represent the family to the outside world.

The institution of motherhood entails the commonly-held belief that becoming a mother "fulfilled" a woman's "nature", that a "good mother" reared "successful" children, and that this was her duty (a ethical undertaking). ${ }^{13}$ Love, as commonly understood in the lexicon of Anglo modernity, is subsumed by duty with its devotion to family wellbeing and honour. This is also true of the institution of marriage: traditionally, "love" is not as highly rated as in modern society, a successful match (which traditionally employed a "matchmaker") would be between class and economic equals, with care taken to investigate the couple's family backgrounds.

By contrast, the consciously modern Greek woman will choose her own marriage partner, if she marries at all (marriage rates have declined while divorce rates are increasing), and then she chooses to restrain her fertility (as the indices, above, show). How may this be reconciled with the cultural value associated with motherhood and family? Such behaviour does reflect contemporary trends in the developed world: in 2007, the majority of women in the United States were living without a spouse. $^{14}$

In the Greek context, however, having few or no children may well be an admission to an inability to fulfil the ideals of being a "good mother", that it is better not to bring a child into the world than to give birth to one who is not given the opportunities to succeed because of inadequate economic resources. ${ }^{15}$ In Greece, a developed country, meeting basic needs is not enough to allow for important life choices such as procreation: there must be the economic and social wherewithal to optimize a child's chances of escaping perceived "poverty".

Ironically, Greek society in its idealized institution of motherhood has aligned itself to Sen's exchange entitlement theory by promoting stage 2 "skill-based endowment", then cultivating opportunity through socio-political networks. This appropriation of the empowerment of the individual by the institution of motherhood reflects on which values of empowerment are most desirable (family-based or individualised) and the way in which economic circumstances may dictate a woman's choice to become a mother. As the president of the Federation of Greek Women, Kalliope Boudouroum-Karata, pointed out during International Women's Day in 2000: "Instead of maternity filling a woman with happiness and providing her with a sense of fulfillment free of obstacles to allow her to respond to her biological right, along with her role in society and the labour market, it fills her with anxiety and guilt which results in a return to a traditional role or the sacrifice of maternity." 16

Prevailing social attitudes in which women are still closely associated with the traditional roles of marriage and motherhood also mean that they are discriminated against when they seek to enter the upper echelons of their professions. Only five per cent of female graduates reach this level. ${ }^{17}$ Moreover, like their rural sisters, they shoulder more of the household responsibility than men. Professional urban-based women are further handicapped than village women by often being deprived of assistance in the home from other family members: the extended family with its support system has given way in large measure to nuclear family households in urban environments. This means a professional woman must rely on inadequate government childcare 
services or employ expensive alternatives (see below) as well as cleaning services if she is to avoid the double burden of maintaining a household and a career. This is not to imply that her country cousin is better off. While rural women do have the family support structure, they lack the opportunities to find employment. A study on the spatial determinants of Greek women's participation in the workforce confirms the known disadvantages of living far from urban centres: "Apart from gender inequalities, Greek women have to deal with spatial inequalities, as well, according to their place of residence." ${ }^{18}$ So geography is also a consideration in exchange entitlement analysis.

Another social institution that negatively impacts on stages 2 and 3 is the media. There remains a significant degree of stereotyping of women which colludes with 'glass ceiling' discrimination. The Greek Consumers Institute (INKA) has identified a number of problematic practices in the media, particularly in advertising: the portrayal of women as objects of sexual desire, as housewives, and as the intellectual inferior of men. ${ }^{19}$ Violence against women is disguised as a cultural issue (as noted above) and hence often normalized: "Violence against women is not generally portrayed in the media as a social problem that violates human rights ... images in the media reinforce the stereotype of men exulting power by being violent, and women exulting femininity and submission by accepting violence and acknowledging its necessity." 20

Finally in the sphere of social institutions, the Eastern Orthodox Church of Christ (Greek Orthodoxy), to which 98 per cent of native-born Greeks belong, may be viewed as a conservative influence on women's exchange entitlement in the modern world. This institution regards itself as the guardian of Greek identity. Its status is enshrined in the Constitution, which proclaims Orthodoxy to be "the prevailing religion". During Ottoman rule, it preserved the Greek language and culture; it also served the cause of national independence by providing "an important rallying point”. ${ }^{21}$ As Susannah Verney has observed: “[A] powerful element of the nationbuilding narrative taught in history classes concerns the role of the Orthodox Church in preserving the Greek nation under Ottoman rule, before the late-eighteenth century national awakening.”22

A Greek woman's identity is therefore circumscribed by the church through its emphasis on her roles of wife and mother. Divorce and abortion, though permitted by both church and state, are frowned upon by the church (abortion for economic reasons is considered perverse). As stated by the Rev. Stanley Harakas, of the Greek Orthodox Archdiocese of America: "Marriage is holy. The home is sacred. Birth is a miracle. In these we find the very meaning of life itself.,"23

A woman is expected to maintain the religious life of the family, such as baptisms, fasting before Easter, celebrating the saints days relevant to family members' baptismal names (traditionally, an individual celebrates his or her 'name' day rather than birthday). These are all part of Greek religious culture which women are expected to uphold and transmit to the next generation. In a very real sense, women are the keepers of Greek identity and the Church defines the contents of that identity.

However, just as the Greek Orthodox Church is being sidelined on the issue of identity, as evidenced by the removal in 2001 of religious affiliation on the national identity card, ${ }^{24}$ so too women are losing their tradition power domain as cultural custodians. Thus urbanisation has led to an expansion in the economic roles that women undertake but it has also deprived them of the authority to preserve and transmit national and religious culture. In becoming more 'European' and therefore secular (the identity card issue of privacy arose from the need to conform to European standards), Greece is moving away from an historic image of itself as a 'backward' Balkan country that languished for centuries under Ottoman occupation only to be kept alive by the Orthodox faith. In a similar vein, women are finding that empowerment comes not from the matriarchal domain of home and hearth but from entry into a European-based economy, society and political framework.

This Europeanisation process, however, did not begin with Greece joining the European Community (now the EU) in 1981. After Greece gained independence from the Ottoman Empire in the early $19^{\text {th }}$ century, Greek society came under greater European influence, with fashion and 
lifestyles being imitated by the Greek elites. This did not necessarily provide emancipation from the traditional expectations of "modest virginity before marriage and fidelity and demure behavior after marriage" in both elite and peasant classes, but added the burden of turning women into "social objects". ${ }^{25}$ Once again, for Greek women, empowerment is a complex proposition and entails discernment between that which adds and that which subtracts from the ability to enjoy "greater individual freedom and a richer cultural life" (Chapter 1).

\section{Types and depth of economic and social poverty that affect women in Greece}

According to Sen, poverty is not only an economic matter but also manifests as socio-cultural and political poverty (see Chapter 1). For Greek women, all three kinds of poverty are evident. Economic poverty results from unequal pay between men and women. With women earning twothirds the pay of a man for the same job, they are one-third poorer than their male equivalents. This is a significant degree of disparity which impacts on a woman's life choices, including whether she has "the economic margin to have children". ${ }^{26}$ Socio-cultural poverty manifests in the continued power of the patriarchy and depiction of women in the media in stereotypical terms. Politically, they are underrepresented in positions of power - whether as bureaucrats or politicians. In 2005, only 7.8 per cent of parliamentary seats were held by women (38 women in the 300-seat parliament): among the lowest proportion in the EU. At the local government level, the quota system calls for 30 per cent representation, but this has yet to be achieved. ${ }^{27}$ At the ministerial level in 2006, three out of 19 were women, including the Minister of Foreign Affairs Dora Bakoyannis. In the high courts, women accounted for less than a quarter of the council of state judges; half of the supreme administrative court judges, and as few as a twentieth of supreme court judges (or 3 out of 62). ${ }^{28}$

Specifically, deprivation scores for Greek women may be estimated as follows:

\begin{tabular}{ll}
\hline GNP per capita & high \\
Life expectancy at birth & high \\
Educational attainment & \\
$\quad$ a. mean years of schooling & high \\
b. adult literacy rate & high \\
Fertility rate & low \\
Maternal mortality rate & low \\
Contraceptive prevalence rate & low \\
Females share in total labour force & medium \\
\hline
\end{tabular}

\section{Discrimination and the Law}

Greek women still spend more time in domestic work than men. After the birth of a child women tend to reduce the time spent in paid employment. Affordable child care is a key issue.

Government daycare centres are unable to cope with demand, and private centres are expensive. The European Union Social Fund will be the source of Greece's funding for more child care centres, ${ }^{29}$ but the results are yet to be felt. It should be noted that EU subsidies flowing into the country account for 3.3 per cent of Greece's GDP. ${ }^{30}$ European standards in a range of sectors are thus not only expressed in terms of rhetoric but also supported by project funding.

As stated above, the 1980s saw major social legislation in favour of women's rights. The Family Law introduced equality of the sexes, adultery was decriminalized, and abortion was legalized. Birth control rights had a positive impact on education and improved living standards. 
As Silvia Pezzini points out: "Only if birth control rights exist and the woman is willing to use them, can the optimal choice of education for men and women be equal." 31

The results of a quarter of a century of increased rights, however, are best described as suboptimal. As noted, women are still well below EU levels of participation in the workforce. Those who have managed to enter the workforce are found predominantly in lower-status, low-skill employment, such as salespersons, service work and the public sector. Men make up two-thirds of high-income employment.

The greatest inequalities in pay are evident not among the unskilled but in those groups that are older, more educated and earn a higher income. ${ }^{32}$ This is despite over half of university graduates being women. The unemployment rate among women is twice that of men; ${ }^{33}$ and for the long-term unemployed, it is three times. The percentage of unemployed young women (42 per cent) is almost twice that of unemployed young men (22.8 per cent). ${ }^{34}$ Women predominate in temporary employment (two-thirds are women) and 28 per cent of women employees work less than 30 hours a week. ${ }^{35}$ The Greek government aims to raise women's participation in the workforce to 60 per cent by 2010, aligning Greece more closely to participation rates in other EU countries. ${ }^{36}$

The Greek Constitution of 1975 established equal rights for men and women. Article 4, paragraph 2, states: "Greek men and women have equal rights and equal obligations.” Article 22, paragraph 1, affirms: "All workers, irrespective of sex or other distinctions, shall be entitled to equal pay for work of equal value.” Greece enjoys strong legislative frameworks at both the state and EU levels. Implementation is a problem, as is women's awareness of labour rights. Sexual harassment, for example, is worse in the southern member states of the EU, like Greece, than the northern ones, as there is a tendency not to treat it seriously or to ensure the provision of awareness-raising programs.

In this respect it is instructive to note that Article 116 of the same Constitution allowed - until the new Article 116 para 2 in the 2001 amendment of the Greek Constitutional - for divergence from equality. In practice, these derogations from equality meant affirmative action such as "quotas at decision-making centers" and "conditional preferences for women when employing and promoting employees” was not taken despite Greece having signed international conventions requiring this. ${ }^{37}$ Greece's National Commission for Human Rights (NCHR) was active in calling for the implementation by Greece of the International Labour Organisation's convention No 111. In its 2002 report, the NCHR called for "particular attention by the Greek state, of affirmative action in favour of women in Greece (following the new Article 116 para 2 of the Greek Constitution) and of the legal and factual equality of sexes in the framework of the relevant, evolving European Community law.” ${ }^{38}$ The Minister of the Interior, Public Administration and Decentralisation, Prokopis Pavlopoulos, speaking at a gender equality conference in Athens in 2004, said further constitutional amendment on gender equality was needed, and Greece should aim to exceed the EU goals as they represented only "minimum requirements." 39

On the whole, however, international treaties have had a positive influence on the rights of women in Greece. A year after Greece joined the European Community (predecessor of the EU), the position of Special Adviser to the Prime Minister on Equality was introduced; while Act 1558.88 established a General Secretariat for Equality, currently under the Ministry of the Interior, Public Administration and Decentralisation, "for the promotion and materialization of the legal and substantive equality in all sectors (political, economic, social, cultural)." 40 The General Secretariat for Equality has sought to bring Greece in line with the provisions on equality in the European Union Treaty of 1992, and have focused on: gender "mainstreaming"; strengthening of equality-promoting mechanisms; attention to employment, better participation in decision-making; combating violence against women; and combating the sexist depiction of women in the mass media. ${ }^{41}$

One area to have escaped the best practices of the General Secretariat for Equality concerns the rights of foreign women, minorities (especially Roma and Turkish women), women in 
detention, and women suffering from sexual exploitation through trafficking. The US State Department's 2006 'Trafficking in Persons Report' criticized Greece for not fully complying "with minimum standards for the elimination of trafficking", though unlike previous years, "it is making significant efforts to do so". ${ }^{42}$ Greece is both a destination and transit corridor for women and children from Eastern Europe, the Balkans, and Africa, who are trafficked for sexual exploitation as well as forced labor. More than 20,000 were reported in 2002 to be "enslaved in forced sex labour". ${ }^{43}$ Once categorized as among the worst offenders in trafficking, ${ }^{44}$ Greece entered a memorandum of cooperation with NGOs for closer government cooperation with their activities on the issue. In 2006, there was a national awareness campaign to for victims, 'clients', and the community. Criticisms still continue with regard to inadequate punishment of traffickers and corrupt government officials who are complicit in the trafficking offences. ${ }^{45}$

\section{Summary of findings and recommendations for actions}

While Greece is renowned for bringing the light of democracy to the world, two classes of people were excluded from this early democracy: women and slaves. Today, women are still struggling to gain equality in practice and not only in legislation. As to slavery, trafficking in foreign women and children has been cited as a continuing concern in Greece's human rights record. Genuine democratic development requires gender equality. In light of Greece's continued human rights failings and the unrealized integration within the polity of women's rights in particular, democracy in Greece remains an unfinished project.

Greek identity, which draws heavily on its illustrious classical past, needs to take stock of itself and its prospects. Gender equality is not an isolated issue. Only when it is addressed in a holistic fashion, and viewed as improving the everyone's quality of life - not only that of women - will Greece's identity as a modern democracy attain its full stature. The Greek Government appears to have recognized this as evidenced by the proceedings of a European conference on gender equality, held in Athens in 2004 within the context of the Long-Term Program of the European Commission on Employment, Social Affairs and Equal Opportunities. Gender equality was identified as a national priority by secretary-general for Equality, Eugenia Tsoumani. She said the Greek government's approach was multi-dimensional in that equality for women was seen as being served on a number of fronts, such as increased participation in the workforce and in addressing the problem of domestic violence. ${ }^{46}$

In the spirit of this quest, a number of recommendations may be made. Government and industry need to provide more family friendly conditions if motherhood, family life and career aspirations are to be compatible rather than mutually exclusive. This calls for the provision of flexible work hours, affordable and ample childcare facilities, and delivery of vocational training programs. Government and NGOs need to raise awareness about preventative contraceptives and women's health issues. Male prejudices about a woman's fertility being a reflection of their own virility must also be tackled. The media is an obvious arena for redressing patriarchal cultural biases, and not only in conveying messages that are specific to contraception. Sexist depictions of women should be more closely monitored and challenged -legally and ethically - if society is to change its underlying view of the role and place of women. Government, NGOs and the media industries all have responsibilities to discharge in this area.

The law must prohibit domestic violence, and not simply treat it within the general assault category. There is also a requirement for a law against spousal rape. Police need to be trained to respond to domestic violence as a more serious offense and not seek to discourage victims from pursuing charges. The courts, too, have a responsibility to hand down heavier punishments to perpetrators. ${ }^{47}$ In this regard, there is scope to tap into potential EU assistance for "gendersensitive policing, with possible exchange programmes for joint training"; and to "promote the 
training of judges in gender and women's rights issues". ${ }^{48}$ Further constitutional amendment on gender equality would underscore the importance of these programs.

As a party to the International Covenant on Economic, Social and Cultural Rights, Greece is bound to respect the rights of its Roman population to adequate shelter and services. It should ensure that the Roma and other marginalized ethnic groups are afforded educational and employment opportunities without discrimination. Continued effort needs to be expended to combat trafficking, in line the Protocol to Prevent, Suppress and Punish Trafficking in Persons, Especially Women and Children (Trafficking Protocol), supplementing the United Nations Convention against Transnational Organized Crime, which Greece signed in December 2000.

In Greece, international law has superiority over domestic law. This is constitutionally recognized. So international treaties to which Greece is a signatory must be upheld. This is the key promoter of women's empowerment in Greece. The traditional patriarchal social structure, on the other hand, may be viewed as the primary inhibitor. Between these two poles, Greek society is attempting to find its balance and to redefine rather than lose its identity. If the forces for progress primarily pertain to formal institutions, and the regressive ones are mainly informal, then greater attention needs to be placed on informal institutional change. This can be done through the assistance of the formal sector in sponsoring programs, such as those recommended above, that encourage a change in attitudes at the community level.

Women themselves are the central players in this change. In this respect the traditional Greek matriarchy of the domestic scene, it would seem, is not so much lost but re-orienting itself. It is facing the challenge of adjusting its role to a world where the European Union has replaced the Ottoman Empire as the arbiter of best international practice in the conduct of culture and society. Successfully negotiating the demands of secular modernity and religious tradition will require cooperation from the Greek Orthodox Church in supporting the empowerment of women. It would thereby reveal the continued relevance of religious belief in shaping modern Greece. Admittedly, the church is socially engaged via such activities as providing shelters for abused women, but it can develop further as an advocate of woman's rights for a more just society. Women, as the traditional custodians of Greek identity, may therefore emerge as co-creators with the religious and secular institutions in redefining what it is to be Greek - and female.

\footnotetext{
${ }^{1}$ Sianou, F. (2000), 'Report from Greece by Our Transnational Partner', European Database: Women in Decision-Making, Country Report - Greece, www.fczb.de/projekte/wid_db/CoRe/Greece.htm (accessed 28.12.06)

${ }^{2}$ Petrinioti, X. (2006), 'Women’s Struggle: An Old Fashioned Title for a Modern Feminist Magazine’, Feminist Movement Archives, Panteion University, www.genderpanteion.gr/en/arxeia.php (accessed 28.12.06)

${ }^{3}$ Coutsoukis, P (2004)‘Greece: The Role of Women’, www.phtius.com/counties/greece/society/greece_society_the_role_of_women (accessed 28.12.06)

${ }^{4}$ Eurostat, http://epp.eurostat.cec.eu.int (accessed 15.1.07)

${ }^{5}$ Cited in Greek Helsinki Monitor (GHM) and the World Organization Against Torture (OMCT) (2002),

'Violence Against Women in Greece', Report prepared for the Committee on the Elimination of Discrimination against Women, July, p.5.

${ }^{6}$ Greek Minister for Labour and Social Security, Dimitris Reppas, cited in Greek Helsinki Monitor (GHM) and the World Organization Against Torture (OMCT) (2002), 'Violence Against Women in Greece'.

${ }^{7}$ Greek Helsinki Monitor (GHM) and the World Organization Against Torture (OMCT) (2002), 'Violence Against Women in Greece’, p. 9.

${ }^{8}$ US Department of State (2006), 'Greece: Country Reports on Human Rights Practices - 2005’, 8 March, www.state.gov/g/drl/rls/hrrpt/2005/61651.htm (accessed 28.12.06).
} 
${ }^{9}$ Sources: IMF (2006), World Economic Outlook; World Bank (2005), World Development Report; CIA (2006), World Factbook; UNFPA (2006), State of the World Population 2006; BBC News (2006), Country Profiles; US Department of State (2006), Bureau of European and Eurasian Affairs.

${ }^{10}$ US Department of State (2006), 'Greece: Country Reports on Human Rights Practices - 2005', 8 March, www.state.gov/g/drl/rls/hrrpt/2005/61651.htm (accessed 28.12.06).

${ }^{11}$ Praxson, H. (2004), Making Modern Mothers: Ethics and Family Planning in Modern Greece, University of California Press; and Correal, A (2005), 'Modern Mothers in Greece'. Athens News, 11

November, p. A35. www.athensnews.gr (accessed 30.12.06)

${ }^{12}$ Praxson (2004), Making Modern Mothers, and Correal (2005), 'Modern Mothers in Greece'.

${ }^{13}$ Praxson (2004), Making Modern Mothers. (Emphasis in the original.)

${ }^{14}$ New York Times report in AFP (2007), 'Most US Women Single', The Australian, 18 January, p. 6.

${ }^{15}$ Praxson (2004), Making Modern Mothers, and Correal (2005), 'Modern Mothers in Greece'.

${ }^{16}$ In 'Struggle for Equality in Work Still a Reality for Greek Women' (2006), Athens News, 10 March, p. A02, www.athensnews.gr (accessed 30.12.06)

${ }_{17}$ Maria Kypriotaki, president of the Union of Greek Women (EGE), cited in 'Struggle for Equality in Work Still a Reality for Greek Women’ (2006), Athens News, 10 March, p. A02, www.athensnews.gr (accessed 30.12.06)

${ }^{18}$ Kritikou, C. and Agorastakis, M. (2006), 'The Participation of Women in the Greek Labour Force: A Spatial Analysis’, European Regional Science Association, ERSA Conference Papers, http://ideas.repec.org/p/wiw/wiwrsa/ersa06p257.html (accessed15.1.07)

${ }^{19}$ Tzilivakis, K (2003), 'Equality Still Failing Women in Greece', Hellenic Communication Service, www.helleniccomserve.com/equality.html (accessed 28.12.06).

${ }^{20}$ Greek Helsinki Monitor (GHM) and the World Organization Against Torture (OMCT) (2002), 'Violence Against Women in Greece', Report prepared for the Committee on the Elimination of Discrimination against Women, July, p.9.

${ }^{21}$ US Department of State (2006), Bureau of European and Eurasian Affairs, 'Background Note: Greece', October, www.state.gov/r/pa/ei/bgn/3395.htm (accessed 3.01.07)

${ }^{22}$ Verney, S. (2002), 'Challenges to Greek Identity', European Political Science, 1 (2), www.essex.ac.uk/ecpr/publications/eps/onlineissues/spring2002/features/verney.htm (accessed 16.1.07).

${ }^{23}$ Harakas, S. (2003), 'The Stand of the Orthodox Church on Controversial Issues', Greek Orthodox

Archdiocese of America, www.goarch.org/en/ourfaith/articles/article7101.asp (accessed 7.1.07)

${ }^{24}$ This was the result of constitutional revision. Besides removing religious affiliation, the new Greek identity cards also no longer include "fingerprints, names and surnames of the cardholder's spouse, maiden names, profession, home addresses, or citizenship”. 'Privacy and Human Rights 2003: Greece’ (2003), www.privacyinternational.org/survey/phr2003/countries/greece.htm (accessed 16.1.07).

${ }^{25}$ Coutsoukis, P (2004)‘Greece: The Role of Women’, www.phtius.com/counties/greece/society/greece_society_the_role_of_women (accessed 28.12.06)

${ }^{26}$ Correal (2005), 'Modern Mothers in Greece'.

${ }^{27}$ Tzilivakis, K. (2002), 'Breaking the Barriers', Athens News, 3 March, p, A09, www.athensnews.gr (accessed 5.1.07).

${ }^{28}$ US Department of State (2006), 'Greece: Country Reports on Human Rights Practices - 2005', 8 March, www.state.gov/g/drl/rls/hrrpt/2005/61651.htm (accessed 28.12.06).

${ }^{29}$ Tzilivakis (2003), ‘Equality Still Failing Women in Greece'.

${ }^{30}$ Bureau of Democracy, Human Rights and Labor (2003), 'Greece: Country Reports on Human Rights Practices - 2002', 31 March, in US Department of State, www.state.gov/g/drl/rls/hrrpt/2002/18368.htm (accessed 3.1.07).

${ }^{31}$ Pezzini, S. (2005), ‘The Effect of Women's Rights on Women's Welfare: Evidence from a Natural Experiment', The Economic Journal, 115 (502), emphasis in the original, published online 2 March 2005, www.blackwell-synergy.com (accessed 28.12.06).

${ }^{32}$ Statistical Office of the EU (Eurostar), cited in Tzilivakis, K (2003), 'Equality Still Failing Women in Greece', Hellenic Communication Service, www.helleniccomserve.com/equality.html (accessed 28.12.06).

${ }^{33}$ Centre for Economic Research (KEPE), cited in Tzilivakis (2003). 
${ }^{34}$ Greek Helsinki Monitor (GHM) and the World Organization Against Torture (OMCT) (2002), 'Violence Against Women in Greece', Report prepared for the Committee on the Elimination of Discrimination against Women, July, pp.5-6.

${ }^{35}$ President of the General Confederation of Workers in Greece (GSEE), Christos Polyzogppoulos, cited in Tzilivakis (2003).

${ }^{36}$ Greek Helsinki Monitor (GHM) and the World Organization Against Torture (OMCT) (2002), 'Violence Against Women in Greece', p.6.

${ }^{37}$ Sianou, F. (2000), 'Report from Greece by Our Transnational Partner', European Database: Women in Decision-Making, Country Report - Greece, www.fczb.de/projekte/wid_db/CoRe/Greece.htm (accessed 28.12.06)

${ }^{38}$ Hellenic Republic National Commission for Human Rights (2003), Report 2002, January.

39 'European Conference on Gender Equality in Politics Opens in Athens' (2004), Athens News Agency, http://www.hri.org/news/greek/apeen/2005/05-02-04.apeen.html\#03 (accessed 13.1.07).

${ }^{40}$ Sianou (2000), 'Report from Greece by Our Transnational Partner'.

${ }^{41}$ Sianou (2000), 'Report from Greece by Our Transnational Partner'.

${ }^{42}$ US Department of State (2006), 'Trafficking in Persons Report', June, www.state.gov/g/tip/rls/tiprpt/2006/65988.htm (accessed 13.1.07).

${ }^{43}$ Cited in Greek Helsinki Monitor (GHM) and the World Organization Against Torture (OMCT) (2002), 'Violence Against Women in Greece', Report prepared for the Committee on the Elimination of

Discrimination against Women, July, p.16.

${ }^{44}$ US Department of State (2002), 'Trafficking in Persons Report' June, www.state.gov/g/tip/rls/tiprpt/2002/10678.htm (accessed 13.1.07).

${ }^{45}$ US Department of State (2006), 'Trafficking in Persons Report'.

46 'European Conference on Gender Equality in Politics Opens in Athens' (2004), Athens News Agency, http://www.hri.org/news/greek/apeen/2005/05-02-04.apeen.html\#03 (accessed 13.1.07).

${ }^{47}$ US Department of State (2006), 'Greece: Country Reports on Human Rights Practices - 2005', 8 March, www.state.gov/g/drl/rls/hrrpt/2005/61651.htm (accessed 28.12.06).

${ }^{48}$ EuroMeSco (2006), 'Women as Full Participants in the Euro-Mediterranean Community of Democratic States', Report produced for the European Commission, April, http://ec.europa.eu/comm/externalrelations/euromed/women/docs/eurom_report0406_eu.pdf (accessed 15.1.07). 